\title{
Promoting Youth Employment in Benue State, Nigeria: A Study of Open Apprenticeship Scheme of the National Directorate of Employment (NDE)
}

\author{
Jeremiah Tersur Vambe ${ }^{1} \&$ Abdulhamid Ozohu-Suleiman ${ }^{1}$ \\ ${ }^{1}$ Faculty of Management Science, Department of Public Administration, University of Abuja, Nigeria \\ Correspondence: Abdulhamid Ozohu-Suleiman, Faculty of Management Science, Department of Public \\ Administration, University of Abuja, Nigeria. E-mail: aburahmama@yahoo.co.uk
}

Received: December 4, 2013 Accepted: January 22, 2013 Online Published: April 29, 2014

doi:10.5539/par.v3n1p105 URL: http://dx.doi.org/10.5539/par.v3n1p105

\begin{abstract}
Youth unemployment has remained one of the present and steady social problems that characterise Nigeria as a developing economy. Measures to address this social problem have featured prominently in the development agenda of successive governments. However, the National Directorate of Employment (NDE), established by the Babangida Administration in 1986, comes across as a consistent public policy on employment and wealth creation that has managed to endure over the years. Since its establishment, a number of schemes have been designed and implemented under the directorate to combat youth unemployment. One of such schemes is the National Open Apprenticeship Scheme (NOAS). This study was undertaken to interrogate the implementation of the scheme in Benue State located in the North Central geographical zone of Nigeria. Within the framework of the neo-classical model of economic thought, these programmes of action are understood as a deliberate policy intervention by government to correct distortions in resource allocation occasioned by the laissez-faire market mechanism. The study employed both analytical and empirical approaches. Whereas the former reflects on state of the research in existing literature, the latter utilized survey research to probe into the implementation of NOAS. Findings reveal that NDE skills development programmes in Benue State is an initiative that can address youth unemployment. However, the objective of enhancing job opportunities through the skills acquisition of NAOS leaves much to be desired. The study recommends among others that; funding of NDE should be improved upon, the scope of NAOS should be expanded to accommodate graduates of tertiary institutions, and the general policy framework on education be reviewed to create a synergy between the formal school system and the job market in Benue State and by extension, Nigeria.
\end{abstract}

Keywords: employment, labour market, policy, skills development, youth

\section{Introduction}

Youth unemployment has remained a disturbing phenomenon that threatens socio-economic progress in sub-Saharan Africa. For a sub-region that is already enmeshed in widespread poverty, the inability of the vast majority of the youth to give full vent to their potentials in the form of gainful employment, paints a gloomy picture of the sub-regional economy. Nigeria, the supposed giant of the region and the most populous in the continent, represents a typical example of this social plague. With a population of about one hundred and fifty million, Nigeria is blessed as the 6th largest producer of crude oil in the world coupled with other capital assets like vast arable land, a variety of mineral resources and human potentials. In spite of these capital endowments, majority of her youth are idle, with nothing to engage their time and energy.

Although, economists from earliest time have articulated theoretical paradigms that provide a framework for diagnosis, prescriptions and prognosis, addressing the problem of unemployment has remained an engaging social issue among public policy experts and practitioners in government. For example, the classical school of economic thought provided a wealth of knowledge on the potency of the free market in optimum resource allocation to stimulate production, employment and socio-economic development. Much of its contribution to knowledge lies in its extensive criticism of government regulation of economic activities. The school argues that government policies should give way to the natural liberty of economic production and trade, and that private property is a sanctified right as a consequence of human labour (Husaini, 2004). However, the Keynesian 
revolution of the 1930s, which commandeered the explosive attack on economic orthodoxy, apparently treated employment as the central focus of its thesis. This was consequent upon the failure of macro-economic system following the great depression. The theory advocated for a reformed capitalism to accommodate government intervention in order to correct distortions in free enterprise, achieve optimum resource allocation and stimulate employment (Schutz, 2004).

Following the precepts of the neo-classical paradigm, the Babangida administration established the National Directorate of Employment (NDE) in 1986. Till date, NDE has remained the only consistent public policy on youth employment and wealth creation in Nigeria. This study examines one of the several schemes of the NDE the National Open Apprenticeship Scheme (NOAS) in Benue State located in the North Central geo-graphical one of Nigeria.

\section{Statement of the Problem}

The National Directorate of Employment (NDE) was established in 1986 to combat Youth unemployment in Nigeria by designing and implementing innovative programmes including the National Open Apprenticeship Scheme (NOAS). NOAS is a programme of the NDE which is designed to provide unemployed youths with vocational skills that could enable them gain employment (Olusoji, 1999). After twenty-four years of its existence, it is regrettable to note that incidence of Youth unemployment in Nigeria, particularly in Benue State has been on the ascendancy. From the figures provided by the National Bureau of Statistics (2009), Benue State had the highest percentage of youth unemployment, with a record high of $(67.4 \%)$ in 2009. Corresponding figures for the other eight states mostly hit are Yobe (19.9\%), Federal Capital Territory (16.4\%), Niger (17\%), Kwara (16.4\%), Kogi (16.5\%), Jigawa (17.4\%), Ekiti (15.6\%) and Delta (18.9\%).

The high rate of unemployment among the youths in Nigeria and Benue State in particular has been traced to poor entrepreneurship development in addition to macroeconomic distortions (Nebo, 2006). This manifest in the number of deficiencies the graduates exhibit in the work place namely; lack of analytical and ICT skills required in the work place; lack of entrepreneurial and problem solving/decision making skills; inadequate technical skills as exhibited by their inability to appropriately apply acquired knowledge to the workplace; ignorance in the use of instruments/equipment due to inadequate practical experience; minimal comprehension of problems and low problem solving ability.

In a similar vein, the World Bank in June 2009 lamented that over 40 million young Nigerians (among whom are youths from Benue State) were out there in the labour market not having decent jobs to keep body and soul together (Ayo, 2009). They lack access to quality food, decent shelter and healthcare delivery. To corroborate this view, the International Labour Organization (ILO), described it as a serious job crisis. Urban jobless rate, it noted was constantly on the increase. Amongst the openly unemployed rural populace almost two thirds are secondary school graduates, affecting between 35 to 50 per cent of them (Ayo, 2009).

Most of the youths in Benue State are in the primary school and secondary (high) school, but many of them would not graduate. They could drop out along the way and others would not go beyond high school. Because of paucity of data, it is difficult to put a figure on high school dropout rates in Benue State, but it suffices to say that the graduation rate is not impressive. Given the general neglect of education and the resultant frequent strike actions by the Academic Staff Union of Universities (ASUU), among other things many of those who enter the university may not obtain a degree, because post-secondary education could drag on for years.

Most streets in Benue nowadays are littered with robust and energetic youths, often secondary schools graduates and high school drop-outs, engaged in motorcycle transport and street hawking. Moreover, not many of the youth who are graduates of universities and other tertiary institutions have the prospect of gaining employment in the state. Most of them lack basic job skills neither do they have skills that would provide them self-employment.

The social consequences of mass youth unemployment in Benue State are many. They include; youth restiveness, armed robbery, rape, and hostage-taking for ransom, illicit drug trade and addiction, as well as political thuggery. There may be no respite for peace-loving inhabitants of Benue State. This is because these unemployed youths, many of who are graduates, read about the blotted bureaucracy of government. They know that about 80 per cent of the annual revenue of the state goes to satiate the pecuniary tastes of the all-conquering politicians, who have turned the nation to their personal fiefdom. This group of self serving politicians make less than 10 per cent of the population. In response, they feel no allegiance to the government as they are alienated in their own country. There is therefore, an urgent need for the state government and other relevant stakeholders to evolve policy measures that will adequately reduce the burden of unemployment and poverty on the youths. One possible approach to reverse this trend would be to increase funding of technical and vocational education and make it 
affordable to enable the youths acquire the necessary skills for jobs and self-employment. A careful appraisal of the situation shows that most of the youths engage in these deviant behaviours because they lack requisite skills and empowerment that can enhance self employment.

Since the implementation of the National Open Apprenticeship Scheme in Benue State is meant to address the problem of poor manpower development, and to correct macro-economic distortions through job creation, this study seeks to address the following questions; how has the NDE fared in its mandate to develop skills and create job opportunities through NOAS?, can the NDE achieve its objective of enhancing youth employment within the context of government funding?, does the business environment in Benue State encourage optimum utilisation of skills and knowledge that the apprentice gain from the training scheme?

\section{Objectives/Methodology of the Study}

The major objective of this study is to examine the National Open Apprenticeship Scheme as a deliberate state intervention to combat youth unemployment. The specific objectives are:

a. to interrogate the Open Apprenticeship Scheme as a policy option to encourage skills acquisition towards promoting youth employment in Benue State;

b. to identify and examine constraint(s) facing the National Directorate of Employment towards realising the foregoing through the Apprenticeship Scheme in Benue State; and

c. to recommend measures that could assist the National Directorate of Employment to achieve the mandate of Open Apprenticeship Scheme in Benue State.

To realise these objectives, the study adopts a multiple perspective approach. These involve a range of research methodology designed to; elicit both secondary and primary data, sample the population of the study, present and analyse the data in a manner that will lead to a dependable conclusion.

For secondary data, the study relied on official reports and a considerable amount of literature that reflects the informed opinion of scholars on similar subject matter of study. The instruments of public and institutional questionnaire were employed to elicit primary data from a sampled population of employees of NDE, trainers and members of the public. The random sampling technique was used to determine the number of target population for the study. This involves two stages of selection. In the first stage, 20 (out of 38) employees of NDE in the state, and 26 (out of 53) trainers making a total of 46 were randomly selected. In the second stage, the study first acknowledged the official population figure of 4,219,244 (2006, Census), distributed among 23 Local Government Areas (LGAs) in Benue State. It then proceeds to select at random, 3 LGAs namely: Gboko, Makurdi and Otukpo. Using the criterion of $10 \%$ as minimum, the population of the three LGAs were reduced to a manageable size of 194 for Gboko, 150 for Makurdi and 110 for Otukpo making a total of 456, for which questionnaire were administered at random. In the final analysis, the institutional questionnaire of 46 adds up to the public questionnaire of 454 to give us a final figure of 500 . Table 1 provides the breakdown.

Table 1. Questionnaire distribution target for selected local govt. areas

\begin{tabular}{cccccc}
\hline LGA & Population & $1^{\text {st }}$ Sample $10 \%$ & $2^{\text {nd }}$ Sample 10\% & Final Sample 10\% & Final Sample \\
\hline Gboko & 358,936 & 35,893 & 3,589 & 358 & 194 \\
Makurdi & 297,398 & 29,739 & 2,973 & 297 & 150 \\
Otukpo & 261,666 & 26,166 & 2,616 & 261 & 110 \\
Total & $\mathbf{9 1 8 , 0 0 0}$ & $\mathbf{9 1 , 7 9 8}$ & $\mathbf{9 , 7 9 8}$ & $\mathbf{9 1 6}$ & $\mathbf{4 5 4}$ \\
\hline
\end{tabular}

Source: Field Survey.

The data collected were presented and analysed using simple percentage and chi-square statistical tools. Simple percentage is expressed as

$$
\frac{X}{N} \times 100
$$

Where:

$\mathrm{X}=$ Number of respondents per opinion 
$\mathrm{N}=$ Total number of subject actually studied in a question

$100=$ Common base

Chi-square tested the hypothesis at $5 \%=0.05$ level of significance. The chi-square formula is given as

$$
\chi^{2}=\sum \frac{(O-E)^{2}}{E}
$$

Where:

$\mathrm{O}=$ Observed frequency $(\mathrm{Fo})$

$\mathrm{E}=$ Expected frequency $(\mathrm{Fe})$

$\Sigma=$ Sigma (summation)

$\chi^{2}=$ Chi-square

\section{Hypothesis}

$\mathrm{H}_{\mathrm{i}}$ : State intervention in the form of skills development enhances job opportunities and therefore generates youth employment.

$\mathrm{H}_{\mathrm{o}}$ : State intervention in the form of skills development does not enhance job opportunities and therefore cannot generate youth employment.

\section{Theoretical Framework}

Much of the literature on development economics is dominated by the theoretical premises of the classical school of thought made popular by Adam Smith's laissez-faire (1776), and the neo-classical school of thought closely associated with Maynard Keynes's interventionist model (1936). Thus, between laissez-faire and state intervention, the goal of development economics has been to achieve equitable resource allocation that will bring about full or near full employment, minimal inflation and general socio-economic progress. However, the great depression of the 1930 and more recently the global financial meltdown of 2009, occasioned by the volatility of the market mechanism, coupled with the problematic of development in the poor nations of Africa, Asia and Latin America, have combined to force a re-appraisal of free enterprise economy. As a consequence, the neo-classical model commonly referred to as Keynesian economics have advocated the imperative of state intervention to remedy the failure of market. The Keynesian model is therefore adopted as our framework of analysis in this study.

In the perspective of the Keynesian model, unemployment results from a situation in which the numbers of people able and are willing to work at prevailing wage exceeds the number of jobs available, and at the same time, firms are unable to sell all the goods at their disposal (NES, 2007). The theory also assumes that money wage-cut is not a solution to problem of unemployment as it reduces income and purchasing power of the people. Such a wage-cut may lead to a full ineffective demand and unemployment may increase. Thus, the problem of unemployment can only be solved by increasing effective demand. Inadequacy of effective demand in Keynes's opinion causes unemployment (Aggarwal et al., 1981).

The most significant departure of the Keynesian theory from the classical model lies in its success in relating academic economics to the economics of government by arguing that economic problems result from a market failure and that the problem can be reduced or solved by appropriate government intervention (Malhotra, 1982). The theory advocates government's intervention in those services which are technically social, particularly for the control of savings and investments in the business cycle and the development of National economic policy.

In the Keynesian paradigm, both industrial and microeconomic policies are secondary to macro-economic policy since the Keynesian macro-economic policy operates on the demand side of the economy (Egbon, 1995). The policy therefore represents an attempt to influence and control output and employment by managing the level of aggregate demand in the economy. But the monetarists argue that this attempt is diversionary from the supply side of the economy. That is to say, the expansion of interventionists leads to inflation rather than full employment and economic growth (Olusoji, 1998). They posit that the problem of economic crisis can only be solved by a cut in public expenditure and allowing market to operate freely. It is important to mention that the monetarist explanation was later adapted by the International Monetary Fund (IMF) and the World Bank, following the advent of a conservative government commitment to monetarism in the leading Western countries that dominates the two Bretton Woods institutions (Olusoji, 1998). But the market is not as free as the monetarists think. The growth of monopolies, oligopolies and other distortions in the world economy has shown 
that the market is not perfect as assumed. As a result of Keynesian thesis, the laissez-faire philosophy of classical economists has been given up. Keynes advocates that the state should intervene in the economy e.g. that government can take steps to increase consumption/investment or both to remove unemployment. Monetary and fiscal policy assumes great significance in determining level of income and employment in the economy (Aggarwal et al., 1981).

Keynesian theory has been criticised for been wholly static and blatantly mechanical. The model has been particularly scored on the ground that its assumption of perfect competition is unrealistic. In reality, perfect competition is not seen rather, imperfect competition and monopolies exist. These existences may result in real wage and employment going up simultaneously. A reduction in this degree of monopoly may lead to a fall in prices of commodities. The constant proportion between employment and output may not hold even before full employment has been reached. An increase in output may occur through better use of capital equipment rather than increase in employment labour.

Despite these criticisms, the Keynesian model is largely useful in analysing the efforts of government in tackling the problem of unemployment in Nigeria. Firstly, the theory believes that as long as there is unemployment, both the government and private individuals and organizations can work together (Aggarwal et al., 1981). Secondly, the theory advocates that government should intervene in the economy for instance, by increasing consumption/investment or both to remove unemployment. These postulations are found to be consistent with the vision and mission that underlie the introduction of National Directorate of Employment (NDE) by the Nigerian government in 1986; to design and implement job creation programmes that will promote attitudinal change, employment generation, poverty reduction and wealth creation among the youths (Abati, 2009). Similarly, its argument that economic problems result from a market failure and that the problem can be reduced or solved by appropriate government intervention has recognised the role of government in combating youth employment in Nigeria through relevant policies and programmes; including the National Directorate of Employment (NDE) Programme.

\section{State of the Research}

Unemployment exists when members of the labour force wish to work but cannot get jobs. It is used in the sense of voluntary decision on the part of a person to choose leisure than work. However, Unemployment should, be seen as an indication of far more complex problem. Thus, to come up with a national policy on which concerted effort for its alleviation could be based, the causes must first be diagnosed. The problem of unemployment in underdeveloped countries has a number of facets that make it historically unique and thus, subject to a variety of economic analyses. It is unique in that it regularly and chronically affects much larger population of the labour force in a variety of ways than open unemployment in industrialized countries; and its causes are much more complex in the underdeveloped countries than developed countries (Abayomi, 1999).

Generally, unemployment arises whenever the supply of labour exceeds the demand for it at the prevailing wage rate. Causes can therefore be analysed from both the supply and demand sides of the labour market in Nigeria. Approached from the supply side, one of the major problems facing Nigeria is rapid population growth. Going by the 2006 census, projections for the future indicate that the population could reach about 145 million by the year 2011 given the annual growth rate of 2.5 percent (National Bureau of Statistics, 2008). A rapid rate of population growth not only puts direct pressure on the total resource base of the country to sustain living standards, but also requires the absorption of increasing numbers of people into the labour market. For instance, if population grows at an annual rate of 2.5 percent, it means that the number of entrants into the labour force after appropriate intervals, will also double every 28 years. When it grows at a rate of 3 percent, the time span is shortened to 23 years (Callaray, 1973). The current 2.5 percent rate of population growth and the resultant age structure are fundamental factors affecting labour market forces/processes in Nigeria. According to Hollister and Goldstein (1994), as the age structure of the population evolves, labour market processes must adapt to existing opportunities in the economy. This is because the processes that are necessary to deal with the increasing number of new entrants into the labour market are quite different from those necessary to sustain an older working population.

One of the root causes of youth unemployment in Nigeria is, therefore, the accelerated growth of population. Its effect on Nigeria's labour market is multifaceted. First, it affects the supply side through a high and rapid increase in labour force relative to the absorptive capacity of the economy. Second, the increase in the number of children in the population presently implies a serious burden. The provision of food, clothing, shelter, health services, education etc, by the state and individual family heads affect investment negatively but favours 
consumption. Consequently, less national resources are made available in Nigeria to expand productive activities and generate employment opportunities.

Another cause which has been discussed widely in the literature is rapid expansion in educational system. Some authors have argued that this rapid expansion increases the number of unemployed people through the quantity and quality of output of the system. Not only have the primary and secondary schools in Nigeria been rapidly expanding during the last two decades, student's enrolment in higher educational institutions have almost tripled (Ojo, 2008). During the last few years, the substantial growth of higher education has been accompanied by increasing difficulties in finding suitable employment by graduates in a variety of courses. This shows that there are imbalances between the supply and demand of these different categories of highly educated manpower. The imbalances reveal themselves in extended periods of job-seeking, underemployment, and even open unemployment. Therefore, rapid expansion of our educational system first acts directly to increase the supply of educated manpower above the corresponding demand for them, and consequently, contributes its quota to the problem of youth unemployment in Nigeria. Second, the existence of few vacancies in some cases for highly qualified manpower relative to educated unemployment shows that Nigeria's higher education system is not properly designed to match education with employment opportunities. There are growing complaints, especially from the private sector, that most of the graduates have become unemployable because they lack the basic skills expected of them. It was a recurrent complaint at the Leon Sullivan Summit in Abuja in 2007, by Nigerians in the Diaspora, who would want to bring their businesses home, but who are not able to find adequately qualified people to man them (The Nigerian Economic Society, 2007).The implication of this for unemployment cannot be overemphasized.

Furthermore, the high incidence of unemployment of secondary school-leavers is a reflection of improper coordination of the education system at different levels to allow smooth transition rate between tiers of education. The large gap between the number of applicants to tertiary institutions in Nigeria and actual placement support this position. This has in no small measure increased the magnitude of Nigeria's youth unemployment problem. It must be acknowledged that when population increases over a long period of time, beyond the labour-absorptive capacity of an economy, unemployment will inevitably be the outcome; but it may not assume the type of complex dimension which rapid educational expansion causes. Educational expansion transforms the labour force and consequently makes the effects of the unemployed segment of the labour force serious in terms of the resource wastage and socio-political problems it may generate.

There is also the issue of rapidly-growing urban labour force; arising from rural-urban migration itself is usually explained in terms of push-pull factors. The push factors include the pressure resulting from rising man-land ratio in the rural areas, and the existence of serious underemployment arising from seasonal cycle climate. These factors are further strengthened in Nigeria by lack of infrastructural facilities which make rural life unattractive. The pull factors include a wide rural-urban income differential in favour of urban dwellers and a presumed higher probability of securing lucrative employment in the cities. Added to these is the concentration of social amenities and infrastructure in the urban centres. This implies that rural areas are neglected in the allocation of social and economic opportunities. Therefore, the unfettered growth of urban unemployment through rural-urban migration has been a direct consequence of government effort to promote both social and economic development of urban areas at the expense of rural areas. Rural-urban migration is a crucial factor in youth unemployment because younger age and mobility decreases with age (Abayomi, 1999).

On the demand side, there is the production technique problem. Technologies emanating from the developed countries are designed in the light of the investment and manpower resources available within these countries. Considering the resources available in Nigeria, these technologies, when borrowed, may not be appropriate. Industrialists and manufacturers, however, take advantage of government fiscal policy measures designed to attract both foreign and private investment by adopting excessively capital-intensive methods of production. Thus, capital-bias in production currently manifests in Nigeria in the form of re-engineering and computerization of business activities, which has led to mass retrenchment in many firms. Casual observation shows that labour is fast replacing machines in manufacturing, mining, construction and other modern sectors. Such increased consciousness of technological transformation in Nigeria, where human resources are abundant, complicates unemployment problems. This occurs through the limitations it imposes on labour.

Another explanation for the low demand for labour and growing open unemployment in Nigeria according to Abayomi (1999) is the government's contradictory economic policy. In response to the demand of the economic environment created by the Structural Adjustment Programme (SAP), the government, at various levels, have had to embark on a drastic cut in the size of Public Sector since 1986. In doing this, not only has government restricted employment into Public Sector, many of its employees have been retrenched. There is also the indirect 
effect of contradictory economic policy manifesting in the form of low consumer income, high production cost due to devaluation, and capacity underutilization. These have contributed significantly to Nigeria's unemployment problem.

Furthermore, wide differences in unemployment rates between states in Nigeria suggest that Nigeria does not have a homogenous labour market. This indicates the presence of some forms of barriers to smooth inter-regional and inter-state movement in search of employment opportunities. This situation cannot be unconnected with the inefficient operation of the Nigeria labour exchange offices which are supposed to provide information on employment opportunities to job seekers. Even if this information is available, some forms of discrimination exist on the bases of tribe, region and religion in Nigeria, with respect to consideration for employment. Such discrimination is, often times, demonstrated through the quota system of the Federal Government, and the reluctance of some State Governments to employ non-indigenes. All these explanations suggest that the imbalance within the Nigerian labour market can be attributed to the diverse, but mutually-reinforcing factors and processes that are operating on both the demand and supply sides of the market. More specifically, these causes have serious effects on the youth employment situation in Nigeria.

This situation underscores the imperative of a study on how the NDE's National Open Apprenticeship Scheme (NOAS) fared in its mandate to create and promote youth employment in Benue State. A probe into the implementation of the scheme might identify areas that the Benue State Government can partner with the NDE in order to make it more effective.

\section{Data Presentation}

Table 2. On job opportunities and youth employment through the Open Apprenticeship Scheme

\begin{tabular}{lllll}
\hline Respondents & Location & Yes & No & Total \\
\hline Members of the Public & Gboko & $\mathbf{1 2 6}$ & $\mathbf{6 8}$ & $\mathbf{1 9 4}$ \\
& Makurdi & $\mathbf{8 7}$ & $\mathbf{2 3}$ & $\mathbf{1 1 0}$ \\
& Otukpo & $\mathbf{1 4 4}$ & $\mathbf{0 6}$ & $\mathbf{1 5 0}$ \\
& Sub-Total & 357 & 97 & 454 \\
& Percentage (\%) & 79 & 21 & 100 \\
\hline Trainers & Gboko & $\mathbf{0 2}$ & $\mathbf{0 1}$ & $\mathbf{0 3}$ \\
& Makurdi & $\mathbf{2 1}$ & $\mathbf{0}$ & $\mathbf{2 1}$ \\
& Otukpo & $\mathbf{0 2}$ & $\mathbf{0}$ & $\mathbf{0 2}$ \\
& Sub-Total & 25 & 01 & 26 \\
& Percentage (\%) & 96 & 04 & 100 \\
\hline Employees of NDE & Makurdi & $\mathbf{1 7}$ & $\mathbf{0 3}$ & $\mathbf{2 0}$ \\
& Percentage (\%) & $\mathbf{8 5}$ & $\mathbf{1 5}$ & $\mathbf{1 0 0}$ \\
& Grand Total & $\mathbf{3 9 9}$ & $\mathbf{1 0 1}$ & $\mathbf{5 0 0}$ \\
& Percentage (\%) & $\mathbf{8 0}$ & $\mathbf{2 0}$ & $\mathbf{1 0 0}$ \\
\hline
\end{tabular}

Source: Field Survey, 2011.

Table 2 contains data that are used to establish whether skills acquired through the Open Apprenticeship Scheme of the National Directorate of Employment have enhanced job opportunities among youths in Benue state. Respondents where sampled from; trainees of various skills acquisition programmes in which beneficiaries of the Open Apprenticeship Scheme are required to undertake their training, members of the public and officials of the National Directorate of Employment in Makurdi - Benue state capital. Analysis of these data in relation to the hypothesis that guided the study is shown in tables 3 and 4 .

\section{Statistical Test}

At the preliminary stage of the study, a hypothesis was formulated to guide and provide focus for the survey research. The questions in the institutional and public survey, which basically seeks to sample opinions on the 
values generated by the training scheme and their impact on youth employment, are closely related to the hypothesis. The decision rule for chi-square statistical test is given as:

If $\mathrm{X}^{2}$ cal. $>\mathrm{X}^{2}$ tab. reject null hypothesis.

If $X^{2}$ cal. $<X^{2}$ tab. accept null hypothesis.

Table 3. Table of independence

\begin{tabular}{ccccc}
\hline & \multicolumn{3}{c}{ Samples } & \multirow{2}{*}{ Row Total } \\
\cline { 2 - 4 } Responses & $\begin{array}{c}\text { Members of the } \\
\text { Public }\end{array}$ & Trainers & $\begin{array}{c}\text { NDE } \\
\text { Employees }\end{array}$ & \\
\hline Yes & $357(362)$ & $25(21)$ & $17(16)$ & 399 \\
No & $97(92)$ & $01(5)$ & $03(04)$ & 101 \\
Column Total & 454 & 26 & 20 & 500 \\
\hline
\end{tabular}

In table 3 the figures outside the bracket represent observed frequency (fo) while the figures inside the bracket represent expected frequency (fe). The table also shows the number of questionnaires retrieved from each category of respondents.

Table 4. Chi-square Distribution Table

\begin{tabular}{ccccc}
\hline Fo & Fe & Fo $-\mathrm{Fe}$ & $(\mathrm{Fo}-\mathrm{Fe})^{2}$ & $\frac{(\mathrm{Fo}-\mathrm{Fe}) 2}{\mathrm{Fe}}$ \\
\hline 357 & -5 & 25 & 25 & 0.06 \\
25 & 21 & 16 & 16 & 0.76 \\
17 & 16 & 1 & 1 & 0.06 \\
97 & 92 & 25 & 25 & 0.27 \\
1 & 5 & -4 & 16 & 3.2 \\
3 & 4 & -4 & 1 & 0.25 \\
& & & & $\chi^{2}=6$ \\
\hline
\end{tabular}

Table 4 shows the value of calculated $\chi^{2}$. It indicates that the value of the calculated $\chi^{2}=6$.

Working for degree of freedom $(\mathrm{df})$

$$
\begin{aligned}
& (\mathrm{c}-1)(\mathrm{r}-1) \\
& (3-1)(2-1)
\end{aligned}
$$

$$
\text { (2) } \begin{array}{r}
\text { (1) } \\
=2
\end{array}
$$

Given the level of significance of 0.05 , the table value of $\chi^{2}$ in the four-figure table $=5.991$.

\subsection{Decision}

Since the $\chi^{2}$ calculated (6) is greater than the table value of $\chi^{2}$ in the four-figure table (5.991) and based on the decision rule which allows us to reject the null hypothesis and accept the alternative hypothesis, it follows therefore, that state intervention in the form of skills development enhances job opportunities and therefore generates youth employment.

\section{Discussion of Findings}

Findings from the study reveal that NDE through its open apprenticeship scheme has recorded considerable achievement in skills acquisition and self employment among a good number of youths in Benue State. It was discovered that NDE has cumulatively supported over 1000 Small and Medium-scale Enterprises (SMEs) 
projects in the state through the Open Apprenticeship Scheme. Such projects include soap making, Welding enterprises, tailoring, computer centres, carpentry, and motor mechanics. With these institutions put in place, NDE has contributed in no small measure to employment generation, growth of industrial output and local sourcing of raw materials in Benue State. Provision of more opportunities for self-employment to a greater number of youths through vocational skills acquisition therefore, requires that the problems inhibiting effective implementation of the Open Apprenticeship Scheme in the State must be ameliorated.

The study also reveals that implementation of the NOAS in Benue State is faced with many challenges. These include; poor business environment, low interest of the youth in the skills development programmes provided by the NDE through the NOAS, low level of education by the trainers, absence of theory classes to complement practical training and so on. From the perspective of the respondents across the sampled population, the major challenge of NOAS in Benue State is funding. 166 respondents representing 33\% of the total sampled population opined that inadequate fund disbursement is responsible for most of the difficulties faced by NDE in the implementation of the NOAS in the state. The problem of inadequate funding was discovered to be responsible for the inability of many beneficiaries of the NOAS in Benue State to practice the knowledge and skills they have acquired through the scheme. The amount of money given to beneficiaries as take-off capital (fifty thousand naira) is not only grossly inadequate given the present economic reality in Nigeria, but they are also dwarfed by a series of conditions to approach any commercial bank for loans. This finding corroborates the discovery made by Olusoji (1999) in his study on Small and Medium-scale enterprises (SMEs) in which he identified the factors that hinder the flow of financial assistance to SMEs in Nigeria generally to include inadequate collateral to secure loans from private credit institutions, poor feasibility studies and lack of equity contribution. According to him, banks are unwilling to give credit to SMEs because of the fear that they may not survive due to lack of functional infrastructural facilities and managerial abilities.

Apart from funding, it was discovered that, the prevailing business environment in Benue State is not supportive of small scale investment which graduates of the apprenticeship scheme usually undertake upon graduation. It was discovered that most of the graduates of the scheme usually lack the markets where the goods they produce are sold. This creates a serious problem for the entrepreneur. For instance, a graduate of the scheme in shoe making is usually given loan to produce after acquiring the necessary skills. Unfortunately, at the initial stage of take-off, the quality and rate of sales cannot sustain him. Therefore, he defaults in repayment of both the interest and principal as at when due. The absence of basic infrastructure like water, electricity, access roads and accommodation make the NDE open apprenticeship scheme ineffective in Benue State. In a survey carried out on poverty in the state by the National Bureau of Statistics in 2006 using Core Welfare Indicators, Questionnaire highlighted the percentage of access to water; access to electricity; and access to credit as 43; 23; and 20 respectively (NBS, 2006). This report by NBS also shows that these social infrastructures are lacking. The implication is that most of the SMEs are forced to resort to private provision of these facilities. This tends to increase their operation cost and often constrains production.

Similarly, the study discovered that there is lack of interest by the unemployed youth in the opportunities for skills acquisition provided by NDE through NOAS. The open apprenticeship scheme like the other NDE job creation programmes principally focuses on the informal sector for self-employment creation. It was discovered that many unemployed youth in Benue State still insist on wage employment to meet their needs instead of availing themselves the opportunities for self-employment provided by NDE through NOAS. The study identified poverty and other social factors such as poor infrastructure development as being responsible for the lukewarm attitude of unemployed school leavers to embrace training for self-employment under the National Open Apprenticeship Scheme.

\section{Conclusion}

Youth employment is the cornerstone of youth development therefore the Benue State government and non-governmental organisations in the state are expected to forge the required partnership to promote employment generation within the framework of a deliberate public policy of NOAS. Although NDE has made noticeable impact in skills acquisition among the youth, empirical findings reveal that there are gaps between expectations and realities as far as the implementation of the policy is concerned. Thus, the study concludes is that the rate of youth unemployment in Benue State has remained high despite the implementation of Open Apprenticeship Scheme. As revealed by the findings, this situation is largely because many of the beneficiaries of the scheme find it difficult to make use of skills they have acquired due to lack of fund to even buy the equipment and tools that they need to practice their trade. Some who have managed to start their own businesses still suffer from lack of patronage, poor electricity supply and other basic social infrastructure that are necessary to enable them operate at a low cost and make profit, hence they remain unemployed. For example, in table 2 
under the presentation of data, majority of the respondents sampled agreed that skills provided by the NDE through National Open Apprenticeship Scheme have not enhanced job opportunities among the youths in Benue State. At best the training programme has only provided them with skills without the enabling environment to make profitable use of their time, energy and the skills they have acquired.

\section{Recommendations}

Guided by the issues discussed and the findings established in the study, the following recommendations are proffered:

\subsection{A Review of the National Poverty Eradication Programme (NAPEP)}

NAPEP should be reorganised to have a nationalistic orientation. By this arrangement, beneficiaries of the National Open Apprenticeship Scheme of NDE who are given stipends to set up their own enterprises should be divided into zones based on specialisation. For instance, the shoe makers should be made to supply the government requisitions for immigration, police, custom, and army boots. The tailors likewise should supply their uniforms instead of importing them. This will in no small way provide the markets to support the productive enterprises of graduates of NOAS.

\subsection{Support of the Benue State Government to NDE Programmes}

Effective implementation of NOAS in Benue State also requires the support of the Benue State government and non-governmental organisations (NGOs) in the state. This can be achieved by implementing policies that would encourage the development of small scale enterprises and stimulate the interest of the youth in the opportunities provided for self-employment by the NDE through NOAS. The establishment of an industrial village will be a step in this direction. This will serve as industrial layout with capital equipment which are highly needed for the improvement of crafts. The industrial village should be provided with critical infrastructural facilities like electricity, water, good communication system and made accessible to trainees of the apprenticeship scheme. The state government and NGOs can also provide financial support to the NDE to organise theory classes for trainees to complement practical training. Similarly, the state government should provide operational vehicles to NDE staff in Makurdi to enhance operational efficiency. In the same vein, the state government can establish consulting agencies to advise the beneficiaries of the scheme on "start-up" issues and other financial and economic counselling. Managerial training for small entrepreneurs should be organised by the state government with emphasis on law, banking and marketing. Training courses should be short, practical and not oriented towards theory.

\subsection{Review of National Open Apprenticeship Scheme (NOAS)}

There is need to review the policy framework of NOAS. At the moment, the scheme accommodates only school leavers and drop-outs. The study reveals that a good number of unemployed youth in Benue State today are graduates of universities, polytechnics and colleges of education who also lack basic skills. The scope of NOAS should be expanded and its services upgraded to include this category of unemployed youth. The review should take into account new technologies and systems. Deliberate efforts must be made by all stakeholders to promote youth vocational training and skills acquisition in all facets of workmanship. To this end, more technological villages should be established in all states of the federation to absorb the youth that will graduate from these technical schools. The National Directorate of Employment must be empowered to increase its capital to provide vocational skills.

\subsection{Review of Educational System}

The Nigeria educational system needs a review and reform to create the required synergy between the formal school system and the job market. This is because, many Nigerians, particularly the youth are largely unemployed due to lack of requisite skills needed in the competitive global employment market. The basic questions that must be answered in the efforts to address the unemployment challenge are: what does work mean in Nigerian context? What is the connection between the school system and the job market in the context of vocational manpower development? At the moment Nigerian leaders seem to be more interested in form rather than substance. In the mean time, the country's education system continues to produce millions of graduates for whom there is no market demand. This must be seriously addressed.

\subsection{Improve Access to Micro-Credit}

There is need for improved access of the youth to micro-credit in Benue State. The involvement of youth clubs or community-based organisations to which the young people belong, that will be guarantors for applicants can help in this regard. The micro-finance banks may be mandated to set aside certain percentage of their loan 
facilities for the youths. Greater access to micro-credit by the youths will reduce unemployment and alleviate poverty among youth and also assist in reducing rural urban migration.

\subsection{Good Governance}

To put Nigerians and indeed the youth in Benue State to work, the solution lies in a refocusing of the nature and purpose of government by the political and bureaucratic leadership. Once upon a time in this country, Nigerians were a busy people; jobs were available, unemployment was low. In Ibadan, Lagos, Onitsha, Kaduna, Enugu, Jos, Port Harcourt, there were industrial complexes where factories produced goods for both consumption and export; and an army of workers-skilled and non-skilled queued up to work and earn a living.

The phenomenal industrialisation wave of the 70 s was such that government had to introduce a number of measures including the Land Use Act in order to remove obstacles in the path of industries. Companies rushed to the universities at the end of every year and later to the National Youth Service Corp (NYSC) camps, to recruit young university graduates. There were expatriates in Nigeria. When Ghanaian economy failed in the late 70s, Ghanaians trooped to Nigeria to look for jobs. All these strides have been lost largely due to leadership failure. That is the inability of Nigerian leaders to rise to the occasion of responsible and responsive leadership. To make a difference, governments at all levels in Nigeria must take practical steps to improve the well-being of the masses. What is required is not rhetoric, not bureaucracy nor politics. Rather, resources of the country should be used in developing the country and not be stolen through inflated contracts, fraud and other dubious and corrupt practices.

\section{References}

2006 Census. Federal Republic of Nigeria Official Gazette May 15 ${ }^{\text {th }}$, 2007. Lagos.

Abati, R. (2009). Nigeria's Unemployment Crisis. The Guardian, Thursday, $26^{\text {th }}$ February.

Abayomi, A. (1999). "he Nigerian Economy. Journal of Economic and Social Studies, 1(2), 16-34.

Aggarwal, I. M., Mehra, S. P., \& Grupta, S. P. (1981). Economic Theory and Problems of Indian Economy. Jullundur Academic Publishing Company.

Ayo, O. B. (2009). Youth Employment - A Must! Retrieved from http://www.unemploymentbomb.23/06/09

Callawary, A. (1973). Youth and Development in the Commonwealth. London: Commonwealth Secretariat.

Egbon, A. (1995). Small and Medium Scale Enterprises: The Nigerian Experience. The Nigerian Journal of Economic History, 1(2), 86-98.

Hollister, R., \& Goldstein, M. (1994). Reforming Labour Markets in the Near East. London: International Centre for Economic Growth.

Husaini, S. B. (2004). Encyclopaedia of Capitalism (Volume II). New York: Fact on File Inc.

Keynes, J. M. (1936). The General Theory of Employment, Interest, and Money. London: Macmillan.

Malhotra, A. K. (1982). MBP Economic Refresher. Jullundur: Malhora Books.

National Bureau of Statistics. (2008). The Nigerian Statistical Fact Sheet on Economic and Social Development, Abuja.

National Bureau of Statistics. (2009). The Nigerian Statistical Fact Sheet on Economic and Social Development, Abuja.

Nebo, C. O. (2006). The Journey So Far. Centre for Entrepreneurship and Development Research (CEDR). Retrieved from http://www.unn.ed.ng./cedr/content/view/120/63 16/12/2009

Ojo, F. (2008). Human Resource Management: Theory and Practice. Lagos: Allied Emant Company.

Olusoji, M. O. (1999). Small and Medium Scale Enterprises: The Nigerian Experience. The Nigerian Journal of Economic History, 1(2), 86-98.

Schutz, D. (2004). Encyclopaedia of Public Administration and Public Policy. New York: Fact on File, Inc.

Smith, A. (1776). In E. Cannon (Ed.), The Wealth of Nations (5th ed.). New York: Bantam Dell, Random House Inc.

The Nigerian Economic Society. (2007). Employment Generation in Nigeria. Ibadan: Daily Graphics (Nig) Ltd. 


\section{Copyrights}

Copyright for this article is retained by the author(s), with first publication rights granted to the journal.

This is an open-access article distributed under the terms and conditions of the Creative Commons Attribution license (http://creativecommons.org/licenses/by/3.0/). 